\title{
The Gender Gap Is a Race Gap: Women Voters in US Presidential Elections - Erratum
}

Jane Junn and Natalie Masuoka

doi: $10.1017 /$ S1537592719003876. Published online by Cambridge University Press, 30 December 2019.

The original version of Junn and Masuoka (2020) published with the wrong article type. It is a Reflection.

The publisher regrets this error. The article has been updated.

\section{Reference}

Junn, Jane, and Natalie Masuoka. "The Gender Gap Is a Race Gap: Women Voters in US Presidential Elections." Perspectives on Politics 18(4): 1135-1145. doi: $10.1017 /$ S1537592719003876. 